\title{
The phylogenetic position of a new species of Plakobranchus from West Papua, Indonesia (Mollusca, Opisthobranchia, Sacoglossa)
}

\author{
María Angélica Meyers-Muñoz', Gerard van der Velde ${ }^{1,2}$, Sancia E.T. van der Meij ${ }^{2,3}$, \\ Bart E.M.W. Stoffels', Theo van Alen ${ }^{4}$, Yosephine Tuti ${ }^{5}$, Bert W. Hoeksema ${ }^{2}$
}

I Radboud University Nijmegen, Institute for Water and Wetland Research, Department of Animal Ecology and Physiology, P.O. Box 9010, 6500 GL Nijmegen, The Netherlands 2 Naturalis Biodiversity Center, Darwinweg 2, 2333 CR Leiden, The Netherlands 3 Oxford University Museum of Natural History, Parks Road, Oxford OX1 3PW, United Kingdom 4 Radboud University Nijmegen, Institute for Water and Wetland Research, Department of Microbiology, P.O. Box 9010, 6500 GL Nijmegen, The Netherlands 5 Research Centre for Oceanography (RCO), Indonesian Institute of Sciences (LIPI), Jl. Pasir Putih I, Ancol Timur, Jakarta 14430, Indonesia

Corresponding author: Bert W. Hoeksema (bert.hoeksema@naturalis.nl)

Academic editor: N. Yonow | Received 29 October 2014 | Accepted 9 May 2016 | Published 30 May 2016

http://zoobank.org/570A4DC3-0CA8-4F7A-967F-3AED002FC3F4

Citation: Meyers-Muñoz MA, van der Velde G, van der Meij SET, Stoffels BEMW, van Alen T, Tuti Y, Hoeksema BW (2016) The phylogenetic position of a new species of Plakobranchus from West Papua, Indonesia (Mollusca, Opisthobranchia, Sacoglossa). ZooKeys 594: 73-98. doi: 10.3897/zookeys.594.5954

\begin{abstract}
Plakobranchus papua Meyers-Muñoz \& van der Velde, sp. n. from West Papua (Papua Barat province, Indonesia), is described based on its external morphology, colour pattern, internal anatomy, radula and reproductive system. In a molecular phylogenetic study specimens of this new species were compared with those of ten candidate taxa under the name Plakobranchus ocellatus van Hasselt, 1824. DNA analyses of COI mtDNA showed a clear distinction between P. papua sp. n. and "P. ocellatus". Plakobranchus papua, sp. n. also differed from all taxa that have been synonymised with $P$. ocellatus. The genus is in dire need of taxonomic revision, preferably based on an integrative analysis involving morphology and DNA of all known Plakobranchus varieties.
\end{abstract}

\section{Keywords}

COI, phylogeny, Plakobranchus ocellatus, reproductive system, Sacoglossa, taxonomy

Copyright Maria Angélica Meyers-Muñoz et al. This is an open access article distributed under the terms of the Creative Commons Attribution License (CC BY 4.0), which permits unrestricted use, distribution, and reproduction in any medium, provided the original author and source are credited. 


\section{Introduction}

Sea slugs of the genus Plakobranchus van Hasselt, 1824 (Order Sacoglossa, Suborder Plakobranchacea) have an elongated body and dorsoventrally flattened, lateral parapodia, which are folded up on the dorsal surface (van Hasselt 1824; Jensen 1992). According to Jensen (1997a) this genus possesses a number of plesiomorphic characters such as an anterodorsal anus, a pharyngeal pouch, triangular, denticulate teeth, a long, curved penial stylet, and the absence of dorsal vessels. The genus also possesses a number of autapomorphies: a broad and flat head, rhinophores located at the anterior corners, mediodorsal eyes on a small papilla, numerous longitudinal dorsal lamellae containing branches of the digestive gland, and a truncate tail; the hermaphrodite ampulla has apparently been lost.

These animals can be found in shallow sandy habitats, crawling over it or halfburied (Gosliner et al. 2008; Mehrotra et al. 2015), or on coral rubble and in rock pools (Yonow 2008) where they consume green macroalgae (Jensen 1993).

Plakobranchus ocellatus van Hasselt, 1824, feeds on a wide variety of marine green algae (Chlorophyta), including at least five species of Ulvophyceae (Wägele et al. 2011). Many studies on Plakobranchus deal with their kleptoplasty, the ability to retain functional chloroplasts from their green algae in their digestive gland cells (Clark et al. 1990; Jensen 1996, 1997a). Species of this genus as well as other sacoglossans belong to the few known animal species with the ability of photosynthesis (Trench 1969; Hirose 2005; Bass 2006; Händeler et al. 2009; Maeda et al. 2010; Wägele et al. 2011; Christa et al. 2013; Yamamoto et al. 2013).

Plakobranchus species are simultaneous hermaphrodites, which possess a penial stylet used in hypodermic insemination. Penial stylets and hypodermic insemination are commonly found within the Sacoglossa (Schmitt et al. 2007; Smolensky et al. 2009). Jensen (1992) also observed extensively branched prostate and albumen glands and a pair of secondary copulatory bursae in Plakobranchus, which are unique for the genus.

During the last decades only Plakobranchus ocellatus has been considered a valid species within the genus (Jensen 1992). This species was described from shallow waters in the Sunda Strait near Anyer, northwest Java, Indonesia. van Hasselt (1824) gave this name because of the blue- and yellow-centred ocellated spots covering the dorsal side and flanks of the body (Figure 1). The original description is based on the species' phenotype and some characteristics of the parapodial lamellae, heart and reproductive system as shown in the original illustrations supplied by van Hasselt (1824). The name Plakobranchus has occasionally been misspelled as Placobranchus, which started when the original description was translated from Dutch to French in 1824 (Bergh 1887; Jensen 1997a, 1997c).

Jensen (1992) studied the anatomy of several Plakobranchus specimens from various Indo-West Pacific locations (Red Sea, Thailand, Guam) and synonymised the previously described species. The descriptions were mainly based on external anatomy, colour pattern and geographic distribution (Yonow 1990, 2008; Debelius 1996; Jensen 1997a; Marshall and Willan 1999; Gosliner et al. 2008) and hardly included descriptions of the internal anatomy as presented by van Hasselt (1824) and Jensen (1992). Plakobranchus ocellatus is now considered the only known valid species of the 

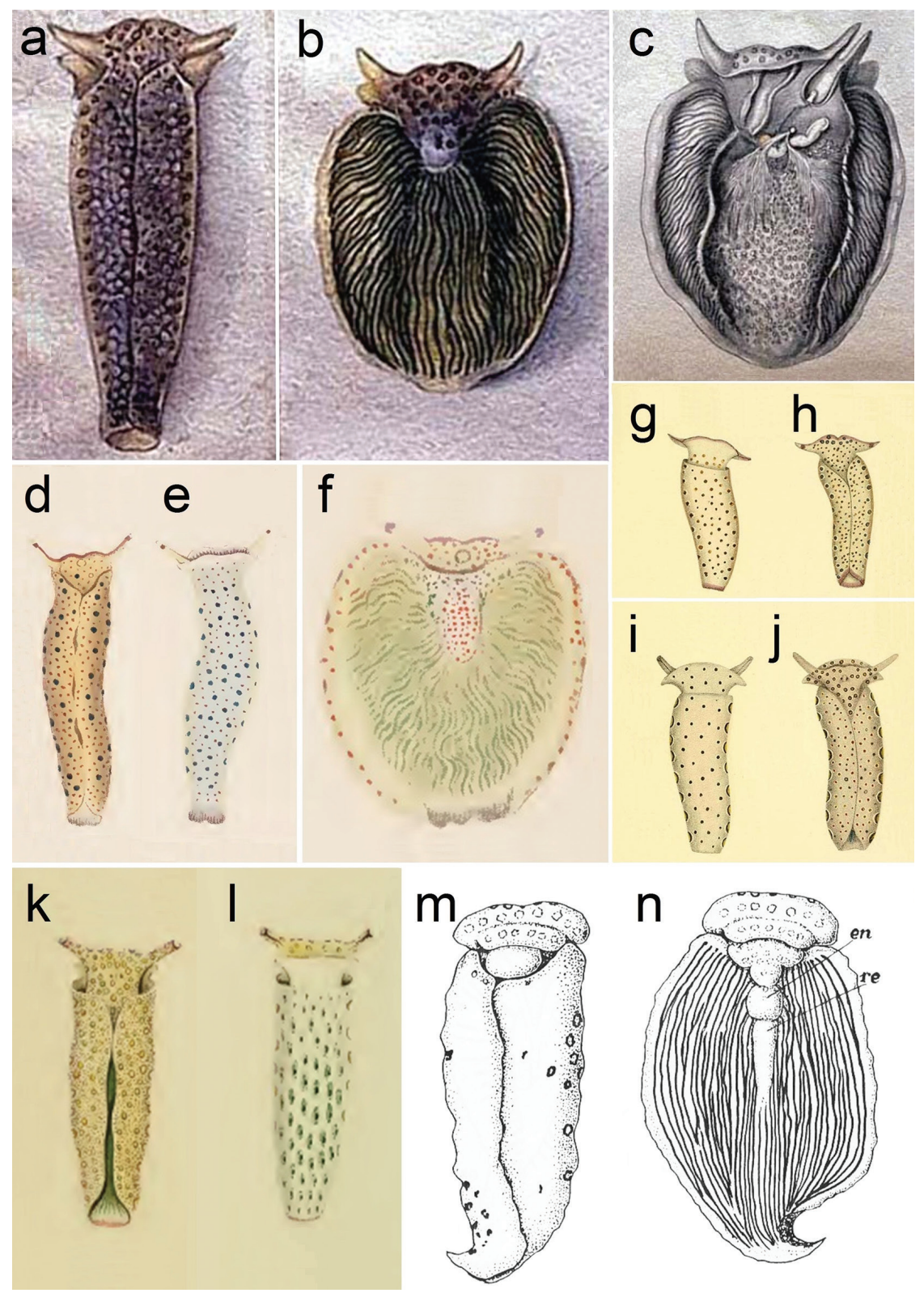

Figure I. a-c Plakobranchus ocellatus, drawings by van Hasselt (1824): a dorsal view with parapodia folded up on the dorsal body surface $\mathbf{b}$ dorsal view with open parapodia, showing longitudinal lamellae c internal anatomy $\mathbf{d}-\mathbf{f} P$. ianthobaptus, drawings by Gould (1852): $\mathbf{d}$ dorsal view with parapodia folded up on the dorsal body surface $\mathbf{e}$ ventral view $\mathbf{f}$ dorsal view with open parapodia, showing longitudinal lamellae $\mathbf{g}-\mathbf{j}$ two Plakobranchus species illustrated by Pease (1871) g-h P. gracilis: $\mathbf{g}$ ventral view $\mathbf{h}$ dorsal view $\mathbf{i}-\mathbf{j} P$. variegatus: $\mathbf{i}$ ventral view $\mathbf{j}$ dorsal view $\mathbf{k}-\mathbf{I}$ drawings of $P$. chlorophacus by Bergh (1873): $\mathbf{k}$ dorsal view with parapodia folded up on the dorsal body surface I ventral view with ocellated spots $\mathbf{m}-\mathbf{n}$ drawings of P. ocellatus by Marcus (1982): $\mathbf{m}$ dorsal view with parapodia folded up on the dorsal body surface $\mathbf{n}$ dorsal view with open parapodia, showing the longitudinal lamellae (en = pericardium; re = renal prominence). 
genus, with ten synonyms and a wide Indo-Pacific distribution (Jensen 2007). This may have been premature (Jensen 1992, 1997a, 1997c), because Gosliner et al. (2008) distinguished two undescribed Plakobranchus species in addition to P. ocellatus. Subsequently, Krug et al. (2013), who used the mitochondrial barcoding gene COI and the nuclear histone 3 gene, found ten distinct phylogenetic lineages in Plakobranchus. This suggests that the taxonomy of Plakobranchus still deserves further study. In the present study a new Plakobranchus species from West Papua, Indonesia, is described and a phylogenetic reconstruction based on the mitochondrial barcoding COI gene is included to show its position within the genus Plakobranchus.

\section{Material and methods}

Twenty specimens were collected by Gerard van der Velde in Indonesia during the 2007 Raja Ampat Expedition (Figure 2; Hoeksema and van der Meij 2008). The specimens were observed alive, photographed, and subsequently preserved in $96 \%$ ethanol. Material analysed in this study was deposited in the mollusc collection of Naturalis Biodiversity Center, Leiden, The Netherlands, and catalogued as RMNH.MOL. One specimen of P. ocellatus (RMNH.MOL.336426), collected in the Philippines, 4 November 1999 (Sta. CEB.01, Cebu Strait, E side of Olango Island 10¹5'54"N $124^{\circ} 04^{\prime} 17^{\prime \prime E}$, coll. BWH) was used for comparison of external characters with the new species in absence of the holotype of P. ocellatus (Figures 7b-d). The original drawings of van Hasselt (1824) are available in scientific archives of Naturalis Biodiversity Center and reprinted here (Figures 1a-c).

To study the radula, the buccal masses of two specimens were dissected and immersed in $10 \% \mathrm{NaOH}$ until the tissue surrounding the radulae was dissolved. The radulae were rinsed in distilled water and transferred to $70 \%$ ethanol. They were subsequently examined by means of a light microscope, photographed, mounted on stubs, and gold-sputter-coated for scanning electron microscopy (SEM). Eight specimens were dissected for anatomical studies. One specimen (Table 1) was dehydrated in a graded ethanol series, embedded in paraffin, and cut into $7 \mu \mathrm{m}$ serial sections with a manual microtome for histological observations. Sections were stained with toluidine blue to identify structures on the basis of metachromasia.

The holotype (RMNH.MOL.336417) and two paratypes (RMNH.MOL.336418336419) of Plakobranchus papua sp. n. were used for DNA analysis. A piece of foot tissue was extracted and treated according the DNeasy Blood and Tissue, spin-column protocol for the purification of total DNA. Primers (LCOI490-HCO2198) were used for the amplification of the mitochondrial gene COI (cytochrome c oxidase subunit, partial) region (Folmer et al. 1994).

PCR reactions were performed with Thermocycle Biometra $T$ professional. All PCR reactions were carried out in $50 \mu \mathrm{l}$ reaction volume, including $25 \mu \mathrm{l} \mathrm{Q}$ PerfeCTa ${ }^{\circ} \mathrm{SYBR}^{\oplus}$ Green FastMix ${ }^{\oplus}$ from Quanta BioScience Inc, (Gaithersburg, USA), $2 \mu \mathrm{l}$ of each primer, $19 \mu \mathrm{l}$ of DPEC treated water and $2 \mu \mathrm{l}$ of genomic DNA. Thermal 


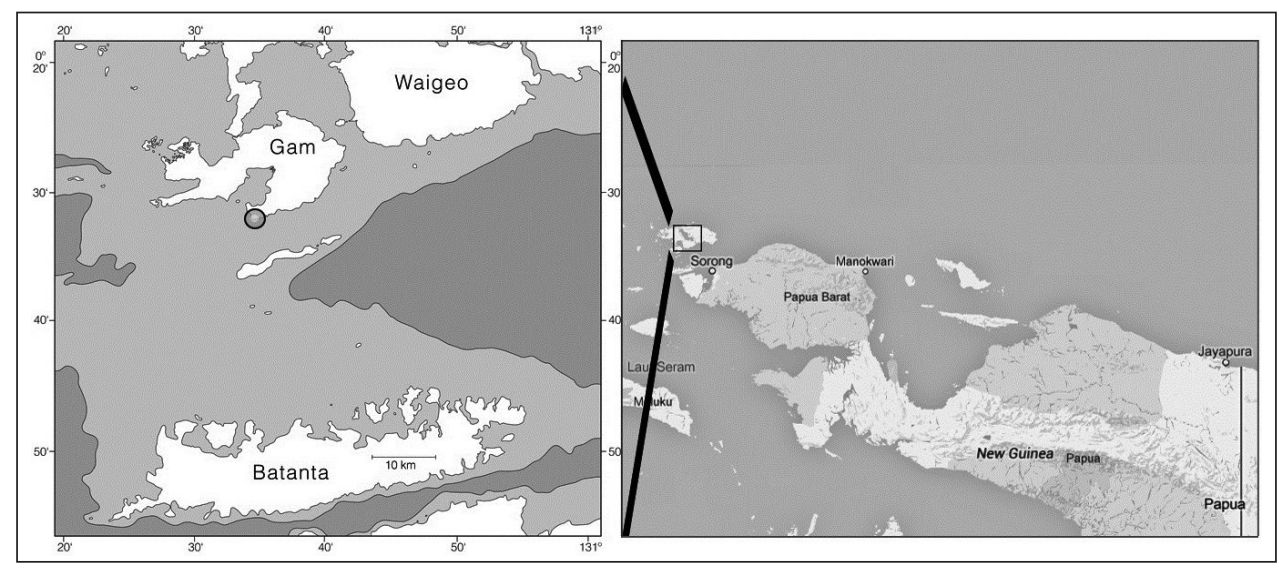

Figure 2. Map of West Papua and Papua, Indonesia, showing the area and locality where Plakobranchus papua specimens were collected: south Gam Island, Mangrove Creek.

cycling started with an initial melting step for 3 min at $94^{\circ} \mathrm{C}$, followed by 39 cycles at $94{ }^{\circ} \mathrm{C}$ for $15 \mathrm{sec}, 50{ }^{\circ} \mathrm{C}$ for $30 \mathrm{sec}$, annealing using a temperature gradient from $50-60{ }^{\circ} \mathrm{C}$ for $1 \mathrm{~min}, 72{ }^{\circ} \mathrm{C}$ for $1 \mathrm{~min}$, and a final elongation step at $72{ }^{\circ} \mathrm{C}$ for $5 \mathrm{~min}$.

The PCR products were purified with a Gene JetTM PCR Purification kit (Fermentas Life Sciences Lithuania) and sequenced directly, using the same primers as for PCR. DNA sequences were obtained using the Big Dye terminator ver. 3.1 Cycle Sequencing kit (Applied Biosystems) and analysed with the automated sequencer ABI 3130 Genetic analyzer at the sequencing facility of the Department of Anthropogenetics at the University Medical Centre, Radboud University, Nijmegen. The sequences were analysed with the program Chromas Lite (Technelysium Pty Ltd.) and deposited in Genbank (KU934191-KU934193).

Phylogenetic analyses were carried out on a dataset of 81 sequences including two outgroup species (Table 1). All COI sequences of Plakobranchus available on GenBank were used, and three newly obtained sequences of $P$. papua sp. n. were added. Elysia ornata (Swainson, 1840) (AB758962) and Thuridilla carlsoni Gosliner, 1995 (GQ996681) were selected as outgroups (Bass and Karl 2006). Sequences were aligned using the Guidance server (ClustalW), resulting in an alignment score of 1.00 for the dataset (Penn et al. 2010). A model selection analysis was carried out in jModeltest (Posada 2008) to select the best-fit model based on AICc (corrected Akaike Information Criterion), rendering $\operatorname{TrN}+\mathrm{G}$ as the best-fit model. A maximum likelihood analysis using the GTR + G model (1000 bootstraps) was carried out in Phyml 3.1 (Guindon et al. 2010) in the Seaview platform (Gouy et al. 2010) and a majority rule consensus tree was constructed. Bayesian inferences (3,000,000 million generations) were estimated in MrBayes 3.1.2 (Ronquist and Huelsenbeck 2003) using the GTR + G model (because of unavailability of the $\operatorname{Tr} N+\mathrm{G}$ model). Average standard deviation of split frequencies was 0.09851 . A majority-rule consensus tree was constructed in MrBayes with a burnin of 25\%, and visualised in FigTree 1.3.1 (http://tree.bio.ed.ac.uk/software/figtree/). 
Table I. COI data from Plakobranchus cf. ocellatus from GenBank, for comparison with the sequence data of Plakobranchus papua sp. n.

\begin{tabular}{|c|c|c|c|}
\hline Species & Accession number & Publication & Collection locality \\
\hline \multirow{28}{*}{$\begin{array}{c}\text { Plakobranchus } \\
\text { cf. ocellatus }\end{array}$} & AB501307 & Maeda et al. 2010 & Okinawa, Japan \\
\hline & AB758968-971 & Takano et al. 2013 & Okinawa, Japan \\
\hline & DQ237996 & Klussmann-Kolb and Dinapoli 2006 & Eastern Australia \\
\hline & DQ471269 & Bass unpubl. & Guam \\
\hline & DQ471270 & Bass unpubl. & Hawaii \\
\hline & GQ996679-680 & Händeler et al. 2009 & Eastern Australia \\
\hline & JX272685-720 & Christa et al. 2013 & Philippines \\
\hline & KC573714-715 & Krug et al. 2013 & Okinawa, Japan \\
\hline & KC573716 & Krug et al. 2013 & Vanuatu \\
\hline & KC573717 & Krug et al. 2013 & Guam \\
\hline & KC573718-719 & Krug et al. 2013 & Okinawa, Japan \\
\hline & KC573720 & Krug et al. 2013 & Philippines \\
\hline & KC573721-722 & Krug et al. 2013 & Guam \\
\hline & KC573723-724 & Krug et al. 2013 & Andaman Sea, Thailand \\
\hline & KC573725 & Krug et al. 2013 & Eastern Australia \\
\hline & KC573726-727 & Krug et al. 2013 & Okinawa, Japan \\
\hline & KC573728-729 & Krug et al. 2013 & Moorea, French Polynesia \\
\hline & KC573730 & Krug et al. 2013 & Guam \\
\hline & KC573731 & Krug et al. 2013 & Okinawa, Japan \\
\hline & KC573732 & Krug et al. 2013 & Sulawesi, Indonesia \\
\hline & KC573733 & Krug et al. 2013 & Philippines \\
\hline & KC573734 & Krug et al. 2013 & Papua New Guinea \\
\hline & KC573735-737 & Krug et al. 2013 & Philippines \\
\hline & KC573738 & Krug et al. 2013 & Hawaii \\
\hline & KC706898 & Leray et al. 2013 & French Polynesia \\
\hline & HM187633-634 & Wägele et al. 2011 & Guam \\
\hline & HM187635 & Wägele et al. unpubl. & Guam \\
\hline & HM187638 & Wägele et al. 2011 & Guam \\
\hline Elysia ornata & AB758962 & Takano et al. 2013 & Japan \\
\hline $\begin{array}{l}\text { Thuridilla } \\
\text { carlsoni }\end{array}$ & GQ996681 & Händeler et al. 2009 & Eastern Australia \\
\hline
\end{tabular}

The web version of ABGD (Automatic Barcode Gap Discovery, Puillandre et al. 2012) was used to estimate the genetic distance corresponding to the difference between a speciation process versus intraspecific variation. Runs were performed using the default range of priors $(\mathrm{pmin}=0.001, \mathrm{pmax}=0.10)$ using the JC69 Jukes-Cantor measure of distance. The analysis involved 25 nucleotide sequences. All ambiguous positions were removed for each sequence pair; there was a total of 657 positions in the final dataset. 


\section{Systematics}

\section{Suborder Plakobranchacea Gray, 1840 \\ Superfamily Plakobranchoidea Gray, 1840 \\ Family Plakobranchidae Rang, 1829}

\section{Genus Plakobranchus van Hasselt, 1824}

Genus diagnosis (emended after Jensen 1992). Genus characterized by a truncate and flattened body shape, flat head, and enrolled rhinophores. Small admedian eyes. Parapodia folded up on the dorsal body surface, parapodial lamellae containing branches of the digestive gland, dorsal vessels absent. Anterodorsal anus. Long curved penial stylet.

\section{Type species: Plakobranchus ocellatus van Hasselt, 1824}

Figures $7 \mathrm{~b}-\mathrm{e}$

Plakobranchus ocellatus van Hasselt 1824: 34-36 (near Anyer, Serang, Bantam, Indonesia; holotype lost); Cuvier 1830: 56; ed. Mason Moll.: 84, pl. 30, figs 7, 7a; Quoy and Gaimard 1833: 319; Bergh 1872: 147-151, pl. XIX figs 1-13; Bergh 1873: 75-76; Vayssière 1912: 111-112, pl. 1 fig. 9; Baba 1936: 19-20; Burn 1972: 177, fig 11; Kay 1979: 454, fig. 144F; Bertsch and Johnson 1981: 20-21; Marcus 1982: 17-18, figs 35-38; Yonow 1990: 288, pl. 2; Colin and Arneson 1995: 176-177, figs 811-812; Debelius 1996: 159, 170; Erhardt and Baensch 1998: 634, 668; Marshall and Willan 1999: 37-38, fig. 48; Coleman 2001: 131; Hirose 2005: 905-916, figs 1-29; Jensen 2007: 278; Coleman 2008: 88-89; Yonow 2008: 56, 124-125, fig: 47; Gosliner et al. 2008: 93-94; Apte 2009: 169, fig. 2a; Hervé 2010: 115; Ramakrishna et al. 2010: 53-54, figs 31, 31 (two images with same number); Yonow 2012: 20, pl. 17; Trowbridge et al. 2011: 2, 6, 8; Sreeraj et al. 2012: 2501. Placobranchus ianthobaptus Gould 1852: 307, pl. 26, figs 407a-c (Honolulu, Hawaii);

Bergh 1872: 166; Vayssière 1912: 47; Ostergaard 1955: 120-122, fig. 8a-f.

Placobranchus guttatus Stimpson 1855: 378-379 (Loo Choo Is.); Trowbridge et al. 2011: 2.

Elysia ocellata Pease 1860: 35 (Sandwich Island, Honolulu).

Placobranchus gracilis Pease 1871: 303, pl. 21, figs 1a-b (Tahiti, French Polynesia); Bergh 1872: 166.

Placobranchus variegatus Pease 1871: 303-304, pl. 21, figs 2a-b (Huaheine, French Polynesia); Bergh 1872: 166-167.

Plakobranchus argus Bergh 1872: 151-165, pls. IX figs 6-9, XVII, XVIII (Honolulu, Hawaii); Vayssière 1912: 111.

Plakobranchus camiguinus Bergh 1872: 167-169, pl. XIX, figs 14-19 (Luzon, Philippines). Plakobranchus laetus Bergh 1872: 171-173, pl. XIX, figs 28-31, pl. XX, figs 1-7 (Masoloc, Philippines). 
Plakobranchus priapinus Bergh 1872: 173-174, pl. XVIII, figs 17-18, pl. XX, figs 8-13 (Bohol, Philippines); Bergh 1905: 81-82, pl. II, fig. 21, pl. XIII, figs 18-19. Plakobranchus punctulatus ? Bergh 1872: 169-171, pl. IX, figs 11-12, pl. XIX, figs 20-27 (Masoloc, Philippines); Bergh 1905: 82.

Plakobranchus chlorophacus Bergh 1873: 76-77 (148-149), pl. IX, fig. 5-6, pl. X, fig. 22-25, pl. XI, figs 3-6 (Huaheine, French Polynesia); Barash and Zeniper 1994: 7.

Placobranchus ocellatus Bergh 1887: 310-311, pl. 6, fig. 5; O’Donoghue 1928: 714; Rao 1962: 253-254, figs 1, 2e, f; Heller and Thompson 1983: 332-334, figs 6AC; Hughes 1977: 92; Jensen 1992: 283-285, figs 22B, 23, 24D-E; Richmond 1997: 266-267.

Plakobranchus sp. Bergh 1905: 82-83 (Kur I., Indonesia); Trowbridge et al. 2011: 3.

\section{Plakobranchus papua Meyers-Muñoz \& van der Velde, sp. n.}

http://zoobank.org/E6FB98EC-AD98-4675-9FC4-0E205A6E3A2F

Figures 2-7a

Type material. Holotype RMNH MOL.336417, length 35 mm (COI, anatomy. Genbank Accession number: KU934191). Paratype RMNH MOL.336418, length 30 mm (COI, anatomy, radula. Genbank Accession number: KU934192). Paratype RMNH MOL.336419, length 34 mm (COI, anatomy. Genbank Accession number: KU934193).

Additional material. RMNH MOL.336420, length $28 \mathrm{~mm}$ (anatomy, radula). RMNH MOL.336421, length $25 \mathrm{~mm}$ (anatomy, radula, penial bulb). RMNH MOL.5010422-5010434, slides of a single specimen, length $30 \mathrm{~mm}$, northeast of Pulau Mansuar (S00 $34.083^{\prime}$, E130³8.525), Expedition Sta. RAJ.38, 30 November 2007 (histology). RMNH MOL.336423 ( $\mathrm{n}=7$ ), length 15-26 mm, east side of Pulau Kri, Sorido Resort lagoon, near Jetty $\left(S 00^{\circ} 33.347^{\prime}\right.$, E130 $\left.{ }^{\circ} 41.225\right)$, Expedition Sta. RAJ.02, 4 December 2007 (anatomy, penial bulb). RMNH MOL.336424, length 41 $\mathrm{mm}$, south side of Pulau Kri (S00 $33.536^{\prime}$, E130 $\left.41.258^{\prime}\right)$, Expedition Sta. RAJ.03, 4 December 2007 (anatomy, penial bulb). RMNH MOL.336425 ( $\mathrm{n}=6$ ), length 15-26 mm, west side of Pulau Yeben Kecil (S00²9.344', E130 30.081'), Expedition Sta. RAJ.48, 6 December 2007 (anatomy, radula).

Type locality. Mangrove Creek, south Gam Island (0³0'403"S, 130³8'986"E), West Papua, Indonesia, 25 November 2007.

Habitat. The specimens were collected in sea grass beds and on coral reef sand between 1 and $10 \mathrm{~m}$ depth.

Etymology. The specific name papua of this species is based on the name of the Indonesian part of New Guinea (provinces Papua and West Papua) where the type material was collected.

Description. External morphology (Figure 3). Body elongated, dorsoventrally flattened with wide parapodial flaps folding along the dorsal midline (Figure 3a). Rhinophores extended from lateral edges of the head long, smooth, rolled (Figure 3b). 

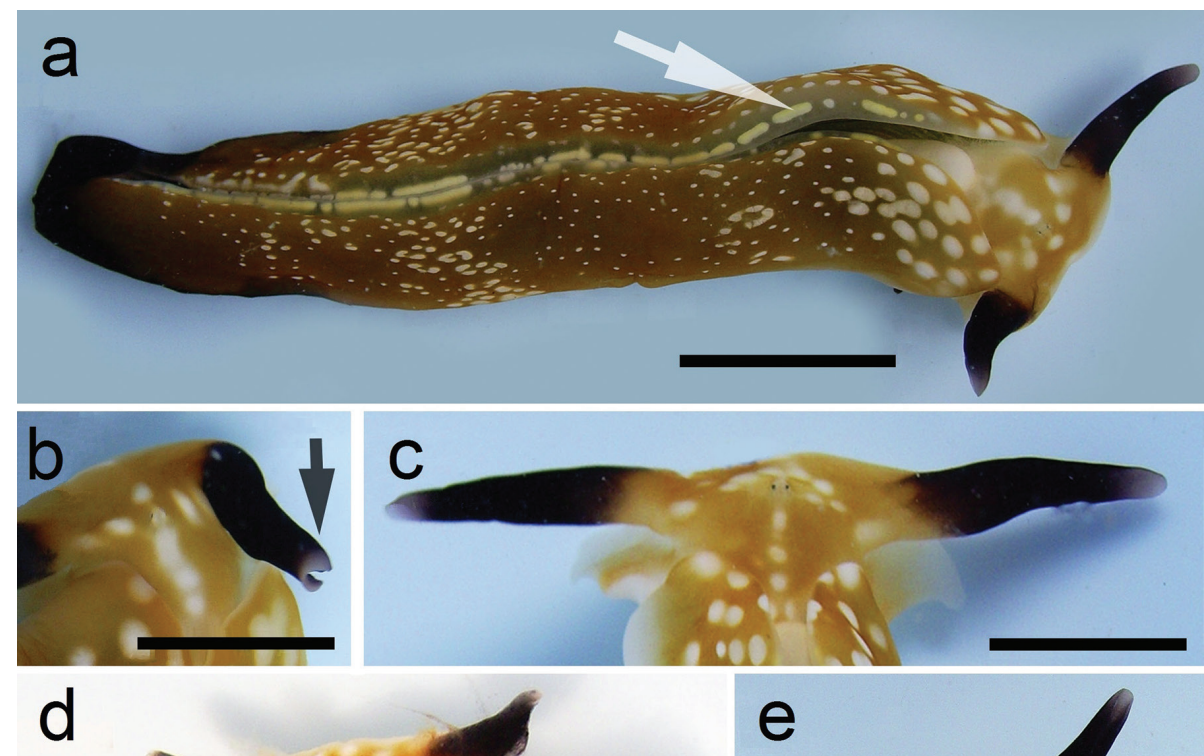

d

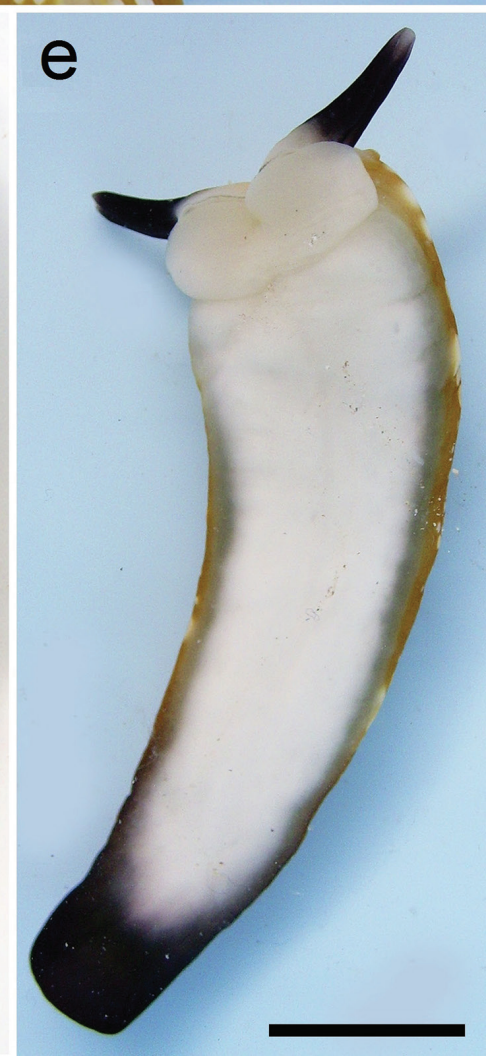

Figure 3. Plakobranchus papua. Images taken from live animals (external morphology). a Dorsal view, parapodia folded up on the dorsal body surface; arrow shows short yellow rod-like spots along the parapodial border $\mathbf{b}$ Dorsal view with detail of the rolled rhinophore indicated by an arrow $\mathbf{c}$ Detail of head, rhinophores, and pedal tentacles $\mathbf{d}$ Open parapodia with lamellae containing branches of the digestive gland and showing renopericardial area e Ventral view of bilobed oral prominence, narrow foot, and truncated black tail. Scale bars: $\mathbf{a}, \mathbf{d}, \mathbf{e}=10 \mathrm{~mm} ; \mathbf{b}, \mathbf{c}=5 \mathrm{~mm}$ 
An eye pair belonging to the central nervous system (CNS) is visible on the head. Eyes situated very close to each other, in front of a prominent, elongated white spot (Figure 3c). The voluminous renopericardial prominence is short, whitish (Figure $3 \mathrm{~d}$ ), and covered by the parapodial flaps. The folded parapodia show a smooth surface from a dorsal view. The parapodia margin at the mid-line shows short yellow rod-like spots along the complete parapodial border (Figure 3a) such as those visible in ' $P$. ocellatus' (Wägele et al. 2011: fig. 1a). When the parapodia are open, the edges appear as soft yellow pectinate margins (Figure 3d). Internally, the parapodia have thick parallel longitudinal lamellae. Only the mid-central lamellae connect directly to the renopericardial prominence and run parallel to each other towards the posterior side of the body. The most external anterior lamellae are shorter, connected through anastomosing lamellae with the most internal lamellae and through them connected with the renopericardial prominence (Figure 3d). These fine dorsal anastomosing lamellae can only be recognized in live and in freshly collected, non-preserved specimens. In preserved contracted specimens it is not possible to distinguish these dorsal anastomosing lamellae. The lamellae possess visible internal granulations corresponding to the digestive gland ramifications, which contain chloroplasts. The genital opening is situated on the right anterior side of the body, just in front of the anterior part of the parapodia, and immediately behind the rhinophore. The anal opening is located on the right anterior side of the pericardium. Ventrally a bilobed oral prominence (Figure $3 e$ ) with a very fine, undulating black line boarding the upper lip is present. Pedal tentacles are short (Figure 3c). The narrow foot has a smooth surface and truncated tail (Figure 3e).

Colouration (Figure 3). Intense ochre body with white spots scattered all over the dorsum, head, and flanks: closest to the head region, on the anterior side corresponding to $1 / 4$ of the body length, the spots are largest, on $2 / 4$ and $4 / 4$ of the body length the dots are smaller, and on the 3/4 of the body length they are larger, but not as large as on the anterior part of the body. Spots are pale white with a thin yellow outline (Figure 7a). Rhinophores black, the outer tips purplish. Internal parapodial flaps ridges bright green to olive green in colour, owing to chloroplasts in the digestive gland. The pericardium region is hyaline white. The pedal tentacles are translucent white. The foot sole is white with a black tail.

Digestive system (Figure 4). The masticatory apparatus was studied in four preserved specimens (RMNH.MOL.336418, 336420, 336421, 336425). The pharynx is connected to the stomach through a short muscular lightly bent oesophagus. The stomach is approximately $25 \%$ smaller than the pharynx. A pair of salivary glands inserted and extended along the oesophagus, reaching the first third of the stomach. The pharynx has prominent dorsal septate muscles. It consists of a large cuticular pharyngeal cavity, the radular sac, and one large ascus, which are also embedded in cuticular material. Uniserial radula, small, approximately 0.50 to $0.75 \mathrm{~mm}$ in length with 15 teeth, eight in the ascending series and seven in the descending series (Figure 4b), and an ascus-sac which varies in size (Figures $4 b, c)$. Teeth are sharp with triangular cusps and 10-14 denticles at each margin side, the teeth measuring 70-75 $\mu \mathrm{m}$ (Figure $4 \mathrm{~d}-\mathrm{g}$ ). 

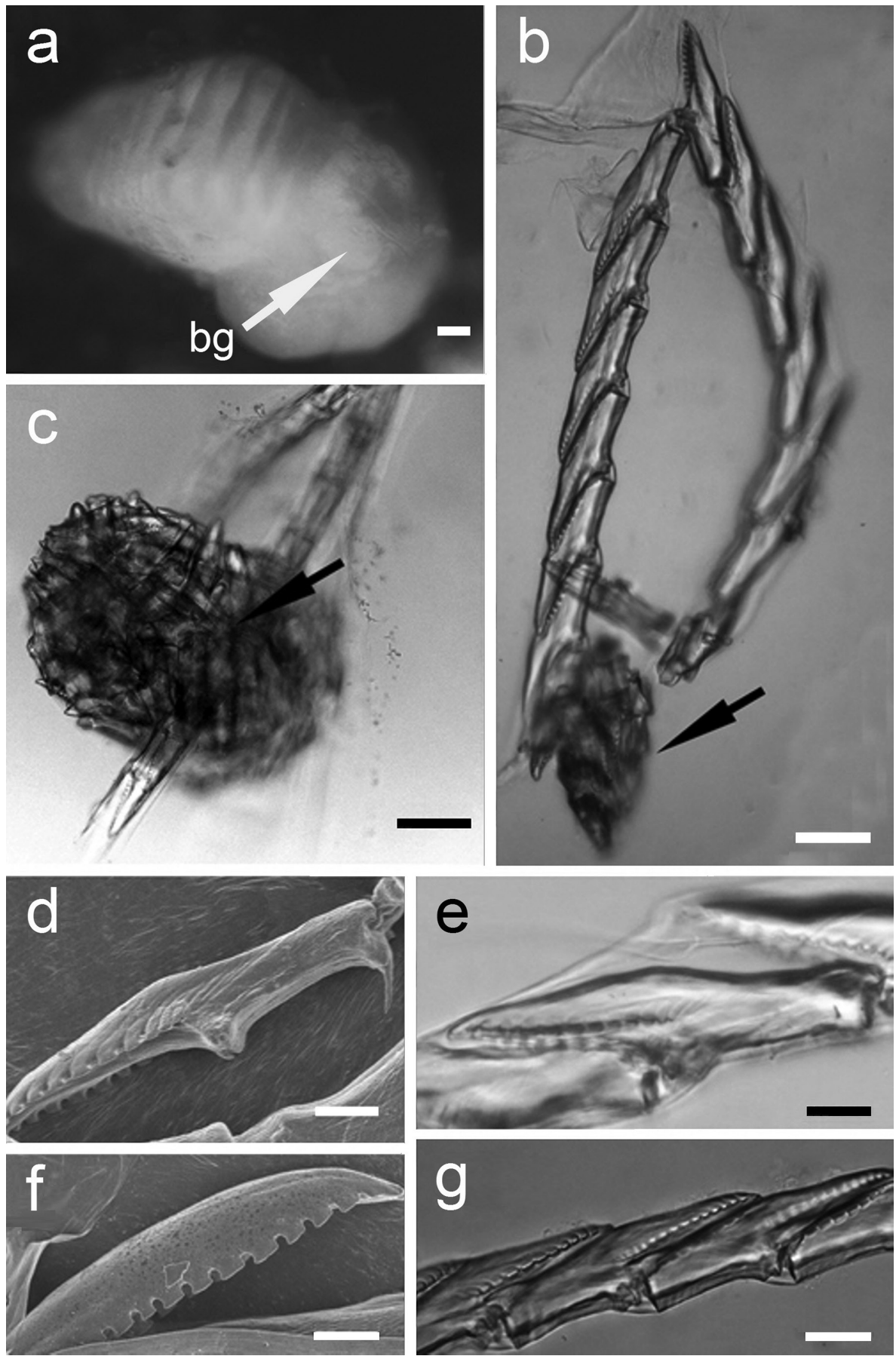

Figure 4. Plakobranchus papua. Masticatory apparatus. a Pharynx; white arrow points to the buccal ganglion (bg) b Radula with ascus-sac (arrowed). c Detail of the ascus-sac which contain used teeth (arrowed) d Tooth, scanning electronic photograph $\mathbf{e}$ Tooth, light microscopy photograph $\mathbf{f}$ Detail of the denticles (SEM) $\mathbf{g}$ Row of teeth (LM). Scale bars: $\mathbf{a}, \mathbf{c}=50 \mu \mathrm{m} ; \mathbf{b}=25 \mu \mathrm{m} ; \mathbf{d}-\mathbf{e}=10 \mu \mathrm{m} ; \mathbf{f}=5 \mu \mathrm{m} ; \mathbf{g}=15 \mu \mathrm{m}$. 


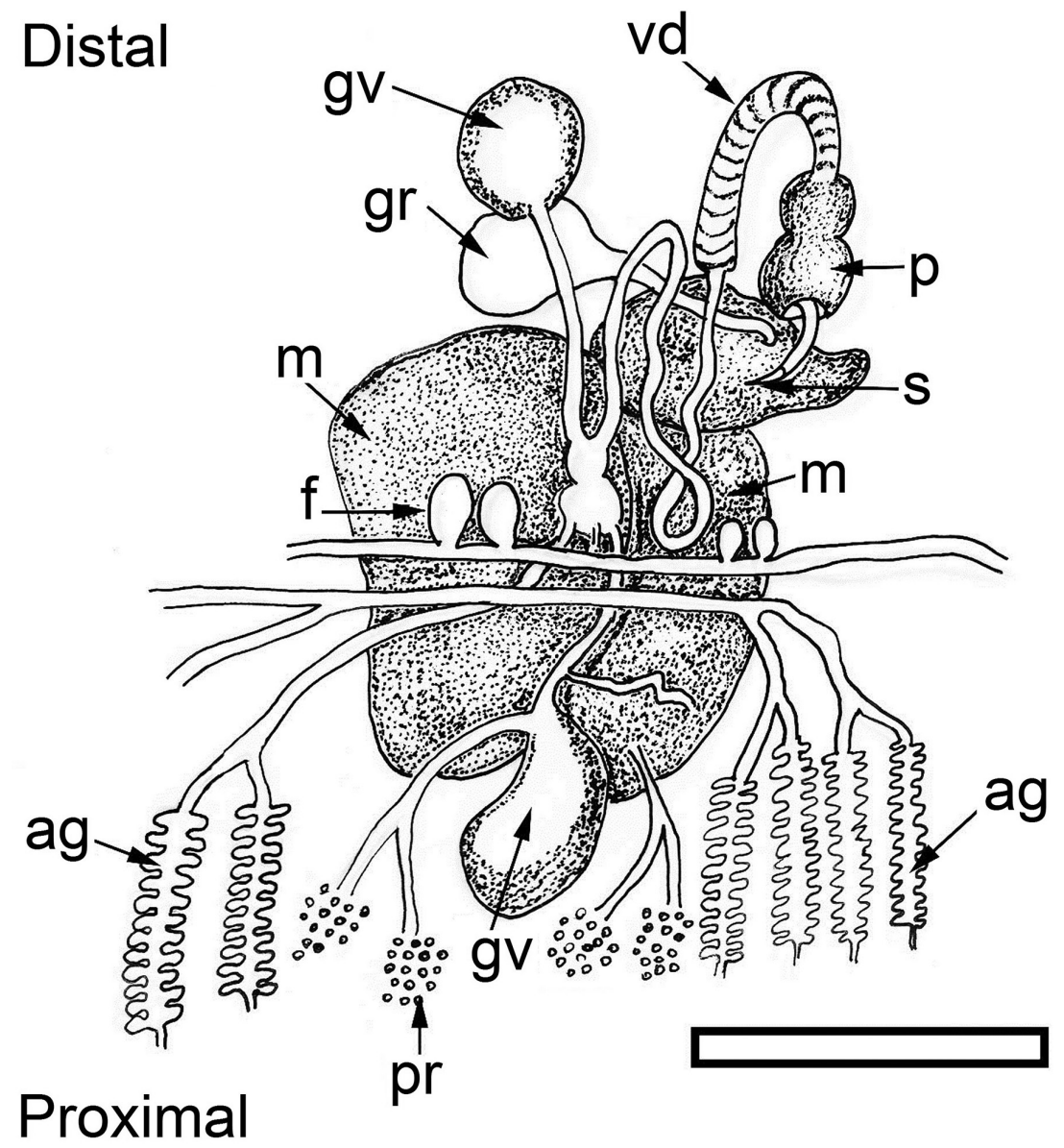

Figure 5. Plakobranchus papua. Schematic drawing of reproductive system (terminology after Jensen 1992). Scale bar: $250 \mu \mathrm{m}$. Abbreviations: ag = albumen gland, $\mathbf{f}=$ follicles, $\mathbf{g r}=$ genital receptacle, $\mathbf{g v}=$ gametolytic vesicle ('bursa copulatrix'), $\mathbf{m}=$ mucus gland, $\mathbf{p}=$ penial bulb, $\mathbf{p r}=$ prostate, $\mathbf{s}=$ penial stylet, $\mathbf{v d}=$ vas deferens.

Reproductive system (Figures 5-6). Occupies almost the central anterior part of the body, at nearly $1 / 4$ of the body length. The distal part of the reproductive system is situated below the heart and directly behind the central nervous system. The penial bulb, which is only approximately $0.5 \mathrm{~mm}$ long (Figure 5: p), is situated below the rhinophores at the same level as the eyes. It possesses a sharp cuticular stylet, which is hollow, with an oblique orifice at the tip (Figure 6). The vas deferens (Figure 5: vd) bends over the mucus gland (Figure 5: $\mathrm{m}$ ), and is orientated towards the proximal area. The distal part of the vas deferens, which is in direct connection with the penial bulb, is muscular and arched. Its proximal part is thin and coiled and is connected to two spherical genital vesicles (Figure 5: gv). After this intersection the vas deferens continues in a proximal 

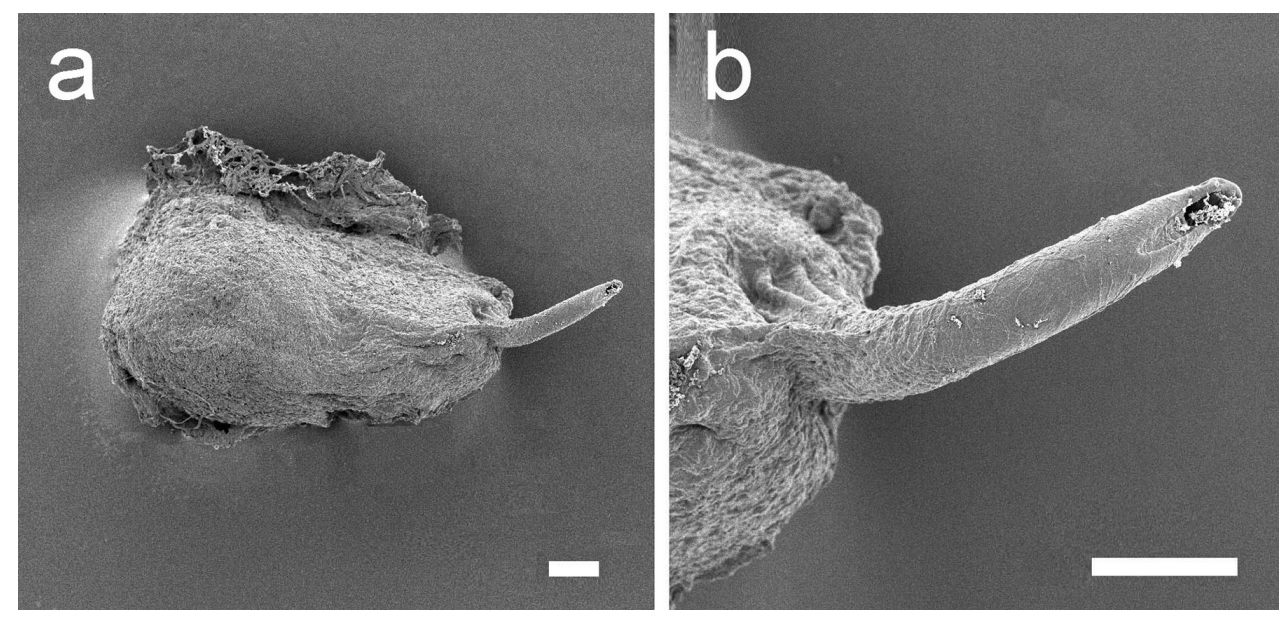

Figure 6. Plakobranchus papua. a Muscular penial bulb and stylet $\mathbf{b}$ Detail of the opening of the stylet. Scale bars: $100 \mu \mathrm{m}$.

direction, where it appears as a short bulky extension, continuing in a thin duct attached to numerous ramifications, the follicles. Underneath this vesicle one large piriform white genital receptacle is present (Figure 5: gr), connected directly to the mucus gland. The mucus gland is large and divided in two lobes. The distal lobe is smaller, a little narrow and coiled. The prostate (Figure 5: pr) and albumen glands (Figure 5: ag) are extensively branched. The terminology used here is similar to the one in the schematic drawing of the reproductive system of $P$. ocellatus by Jensen (1992: fig. 22B).

Central nervous system. The central nervous system is located at the anterior part of the oesophagus and forms a circumoesophageal ring, consisting of a very small pair of buccal ganglia, a large pair of fused cerebro-pleural ganglia, and a pair of pedal ganglia. The CNS consists for the main part of the cerebral and pleural ganglia. The eyes of the CNS are situated very close to each other.

DNA analyses (Figure 8). The molecular phylogeny reconstruction of the genus Plakobranchus contains all the currently available sequences on GenBank. The analyses in MrBayes (Bayesian inference) and Phyml (maximum likelihood) resulted in trees in which the specimens were assigned to the same clades. In Phyml the tree formed a polytomy, whereas the analyses in MrBayes showed a topology with highly resolved clades. Ten different clades can be distinguished, of which three are represented by single specimens. The largest clade contains 49 sequences. Our new species groups with Plakobranchus sp. 1 of Krug et al. (2013) from Sulawesi, Indonesia and Panglao, Philippines. Over 580 base pairs there is a difference of $1.2 \%$ ( $7 \mathrm{bp}$ ) between our specimens and the specimens of Plakobranchus sp. 1 from Krug et al. (2013).

The ABGD analysis resulted in prior maximal intraspecific divergence of ca. 0.07. Values higher than the maximal intraspecific divergence resulted in 10 Molecular Operational Taxonomic Units (MOTUs) in both the recursive and initial partition. Each 

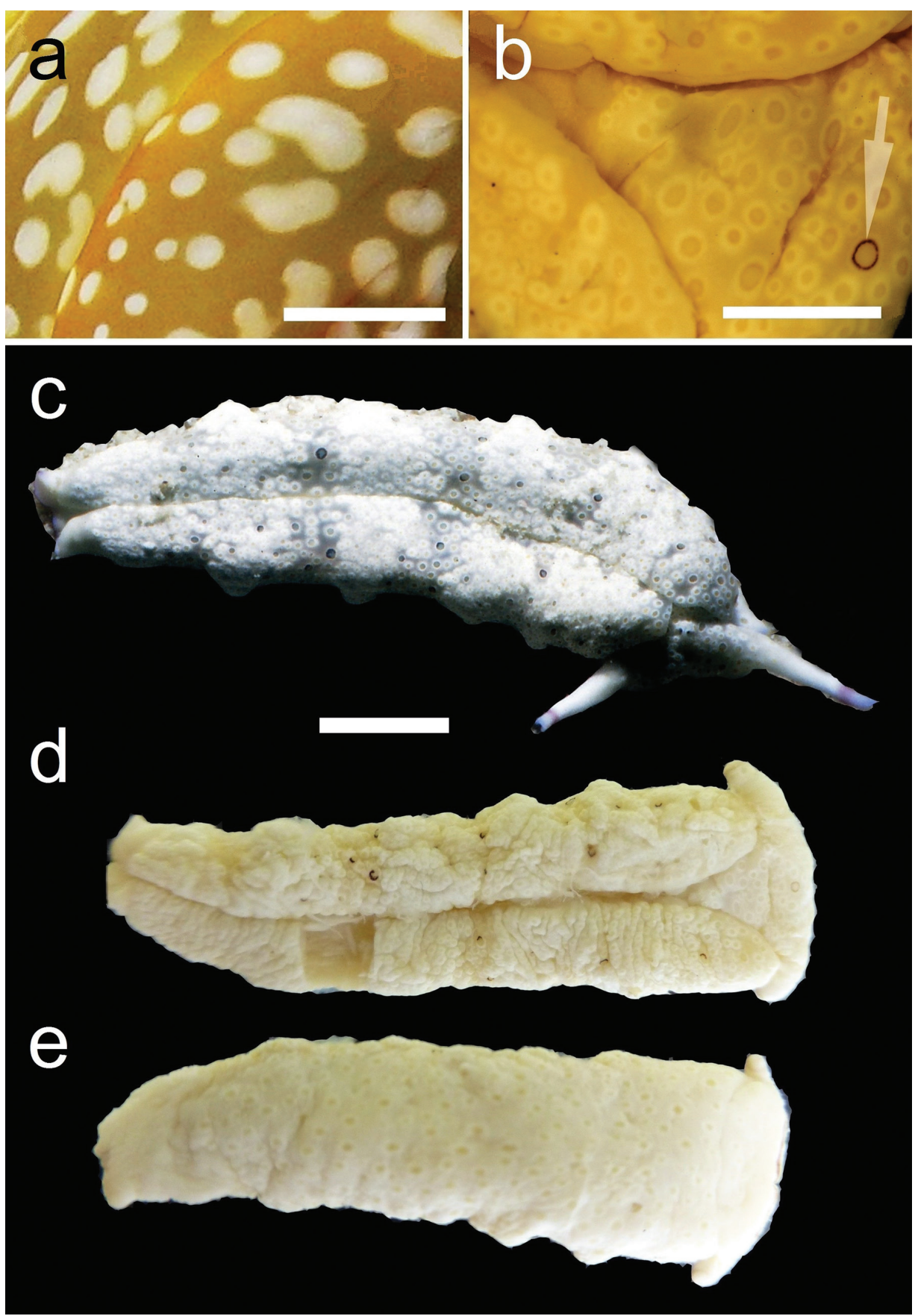

Figure 7. a Dorsal view of a preserved Plakobranchus papua showing white dots surrounded by a yellow outline. b Preserved $P$. ocellatus, ocellated spots with dark pigment surrounded by a white ring, some with a black ring (arrowed). c P. ocellatus, dorsal view of a live animal (Cebu, Philippines, 1999, photo BWH). P. ocellatus, (d) dorsal view and (e) ventral view of preserved animal. Scale bars: $\mathbf{a}, \mathbf{b}=5 \mathrm{~mm}$, $\mathbf{c}-\mathbf{e}=10 \mathrm{~mm}$. 


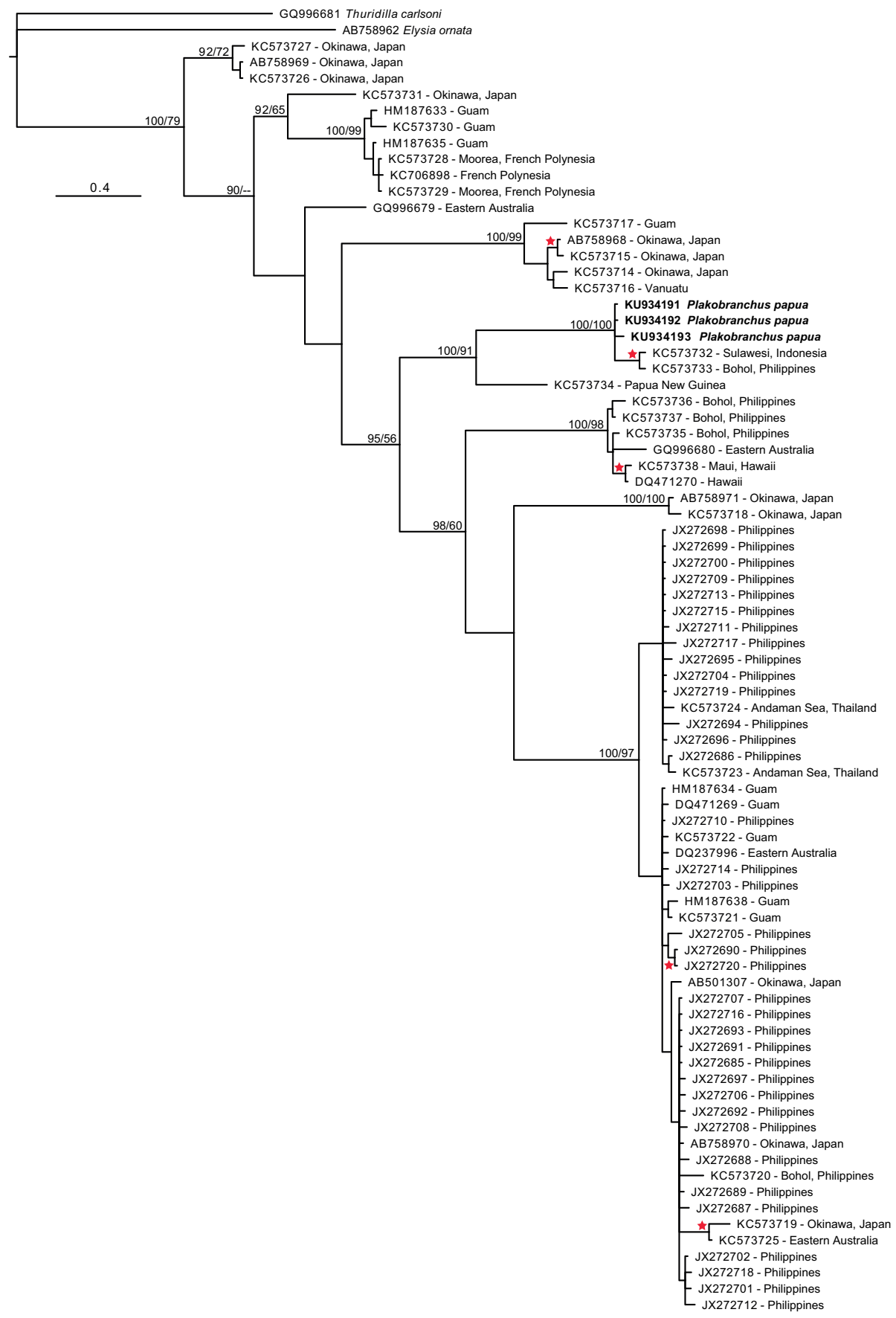

Figure 8. Phylogram of the Plakobranchus ocellatus species complex, topology derived from MrBayes analysis. Support values represent Bayesian posterior probabilities / ML. Numbers refer to GenBank codes. Red stars represent nodes with Bayesian probability values $>90$ and high ML values. 
of these MOTU's corresponds to a clade in the phylogeny reconstruction (Figure 8). The three singletons (GQ996679, KC573731, KC573734) from the ABGD analysis were also retrieved as singletons in the molecular phylogeny.

\section{Discussion}

Plakobranchus papua sp. n. differs not only from P. ocellatus as illustrated by van Hasselt (1824), but also from several other Plakobranchus colour varieties, which can be found at SeaSlugForum and NudiPixel. Colour variations of Plakobranchus and geographical distributions are presented in Table 2. Based on this data several species of Plakobranchus are to be expected. The new species differs from all other descriptions and illustrations of individuals ascribed to $P$. ocellatus by a clearly different colour pattern, with black rhinophores and tail, non-ocellated spots, and a foot sole without spots. Plakobranchus papua sp. n. also differs externally from all taxa that have been synonymised with $P$. ocellatus in the colouration, distribution of spots, and the absence of real ocellated spots. DNA analyses of COI mtDNA show a clear distinction between P. papua sp. n. and P. ocellatus s.l.

The original drawings of $P$. ocellatus made by van Hasselt (1824) do not show many details (Figure 1), but enough to separate it from $P$. papua sp. n. The dorsum and flanks of $P$. papua sp. n. have white spots, while $P$. ocellatus possesses ocellate spots with dark pigment surrounded by a yellow ring or surrounded by a black ring (Figures 1, 7). These large ocellate spots of $P$. ocellatus are also present all over the foot sole, while in $P$. papua sp. n. the foot sole is white without any spots. Furthermore, the ocellate spots of $P$. ocellatus are very abundant all over the dorsum in combination with broad transverse stripes of darker or lighter pigment. These ocellate spots are abundant on the dorsum of the preserved specimen (Figure 7c, d) and less abundant on the ventral part of the body (Figure 7e). The tail of $P$. papua is black, while in P. ocellatus only the margin of the tail has dark pigment. Bergh (1872) described the radula of P. ocellatus as consisting of 19 teeth, eight ascendant teeth, one not developed, one tooth at tip and nine descendant teeth, and between 90 to 100 teeth inside the ascus. The teeth possessed up to 14 strong denticles at each side. In P. papua the shape of the teeth appears more arched than the teeth of $P$. ocellatus described and figured by Jensen (1997a). In our specimens of $P$. papua the number of teeth is similar, and the lateral denticles ranged between 10 and 14 in number. In the SEM photos of $P$. ocellatus by Jensen (1992) at least 10 denticles can be counted. The illustrations presented by Bergh (1873: Plate XI figs 5, 6) for P. chlorophacus show 10-11 denticles. Within Sacoglossa, species like Elysia viridis (Montagu, 1804) are able to modify the teeth size and shape in response to changes in their diet (Jensen 1993) but it is not known if this ability also exists in Plakobranchus.

Wägele et al. (2010) discovered special glandular structures on the dorsoanterior to lateral parts of the pharynx in $P$. ocellatus. Similar glands were found surrounding the pharynx in $P$. papua, and stained dark blue when treated with toluidine blue. 
Jensen (1997a) described a pair of copulatory bursae in the reproductive system of P. ocellatus, which were also found in P. papua sp. n. (Figure 5: gv).

When comparing the drawings of the P. ocellatus holotype (Figure 1a-c) and those by Marcus (1982) of specimens collected in the Farasan Islands, Red Sea (Figure 1m, $\mathrm{n})$, differences can be observed between both sets of illustrations. The schematic drawing made by Marcus (1982) is based on one preserved specimen and shows some scattered large ocellated dorsal spots and a line of ocelli along the head (Figure $1 \mathrm{~m}$ ). In the P. ocellatus described by van Hasselt (1824) the renopericardial area is fused together and appears as a nearly rounded prominence, while in the specimen illustrated by Marcus (1982) the pericardium is separated with respect to the renal prominence and this renal prominence is very elongated (Figure $1 \mathrm{n}$ ), which is not confirmed in the text (Marcus 1928). Since Red Sea specimens externally resemble P. ocellatus s.s. (Yonow 1990, 2008), these differences need more study before they can be considered reliable. In this regard, it is noteworthy that Plakobranchus papua possesses a shorter renopericardial area as that illustrated by van Hasselt for $P$. ocellatus.

Marcus (1982) used the absence of dorsal vessels in Plakobranchus to separate this genus from Pattyclaya (which possesses clear dorsal vessels) and Jensen (1992) also used this same absence to separate Plakobranchus from Elysia. Plakobranchus species have tiny anastomosing lamellae connecting the external lamellae to the most internalones. In $P$. papua fine short dorsal anastomosing lamellae connect the anteriormost external lamellae with the most internal ones, which are in direct connection with the renopericardial area. This is endorsed by Wägele et al. (2010), who stated that the Plakobranchidae are characterized as follows: "a number of pericardial vessels are found branching from the pericardium along the dorsal surface of the body and parapodia".

The new COI sequences were used in a phylogenetic analysis together with the 76 sequences available in GenBank under the name P. ocellatus from various Indo-West Pacific localities (Figure 8). The phylogenetic analysis shows that P. papua with Plakobranchus sp. 1 from Krug et al. (2013) are in the same cluster, and separated from all other $P$. ocellatus sequences. Solely based on COI, $P$. papua could be considered the same species as Plakobranchus sp. 1 of Krug et al.(2013). This would imply that $P$. papua is not restricted to West Papua but also occurs at Panglao Island (Philippines) and Sulawesi (Indonesia).

The ten groupings retrieved in our $\mathrm{ABGD}$ analysis and phylogeny reconstruction (Figure 8) agree with the results of Krug et al. (2013). Thus, although morphological analyses indicate a single highly polymorphic P. ocellatus (Jensen 1992, 1993, 1996, 1997a, 1997b, 2007), molecular analyses indicate a species complex containing ten candidate species. Christa et al. (2013: fig. 1b) identified a specimen from Guam as $P$. ocellatus, but according to our Plakobranchus colour pattern and distribution review (Table 2), this specimen resembles $P$. ocellatus var. A more closely. Unfortunately the GenBank accession numbers cannot be linked to their illustrated specimens. Krug et al. (2013) stated that some differently coloured Japanese specimens could also be considered separate species. The eleven varieties of $P$. ocellatus found in the web and publications (one of which is $P$. papua sp. n.) could not be linked because Krug et al. (2013) 


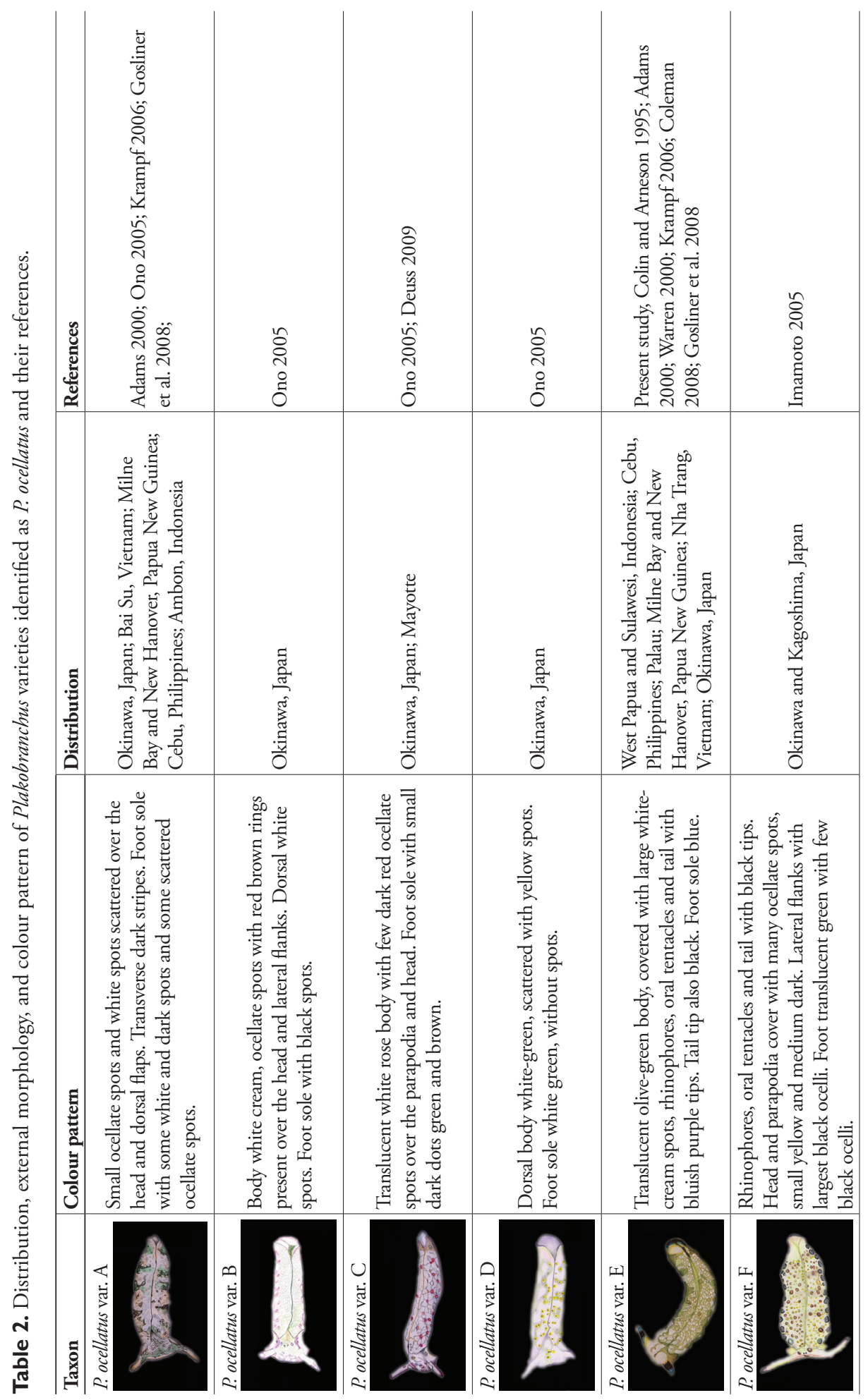




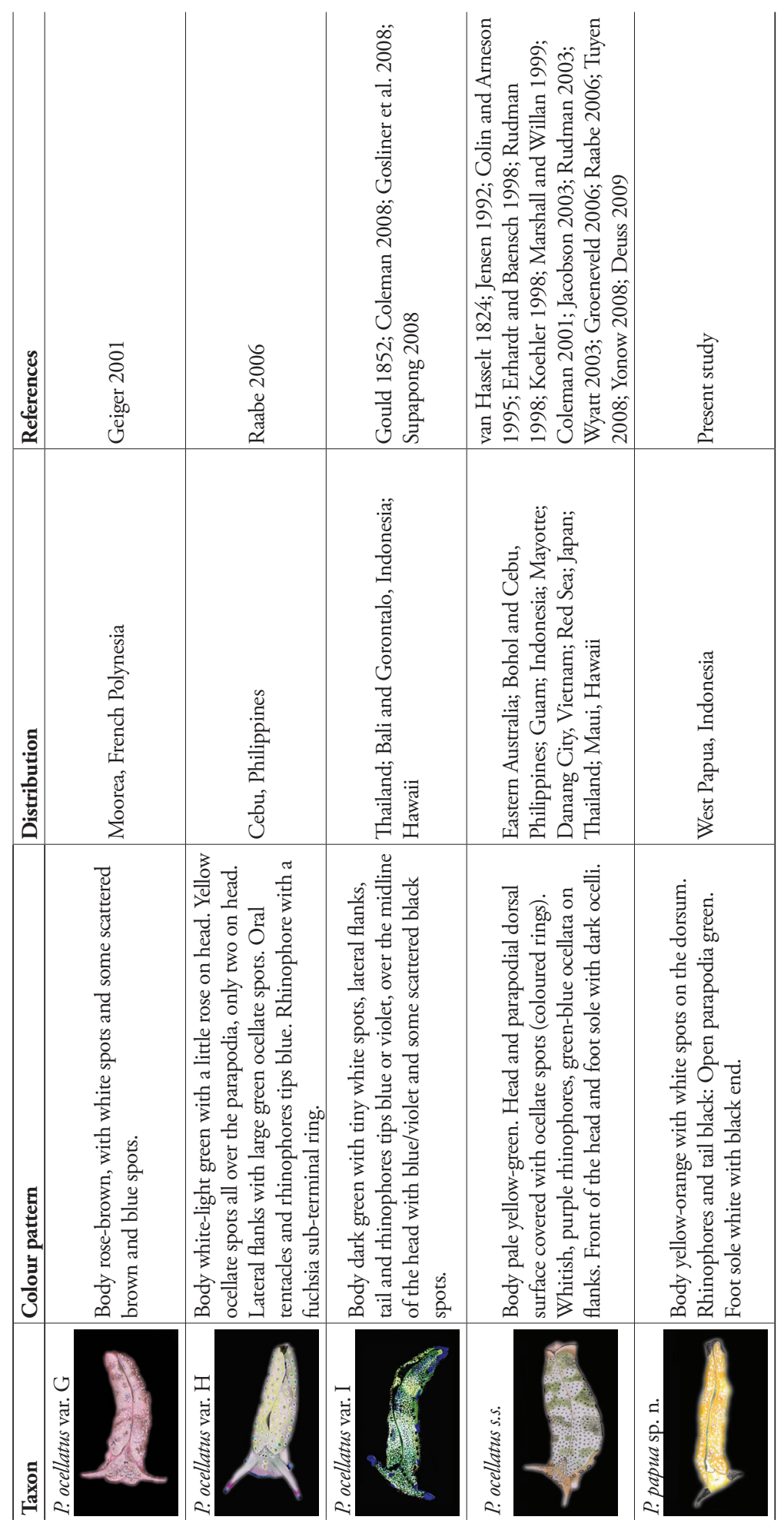


did not provide enough information on the morphology and colouration pattern of their specimens, nor did they include illustrations. Based only on phenotypes of images retrieved from the internet, eleven varieties of Plakobranchus were distinguished, including P. ocellatus (sensu stricto) and P. papua sp. n. (Table 2). All Plakobranchus species and varieties were recorded from the Indo-West Pacific, including the Red Sea.

Further research on the genus Plakobranchus based on morphology and DNA is necessary to unravel the phylogenetic and taxonomic relationships within this genus, with clear illustrations included of the external morphology. The present study shows that in situ photographs are indispensable to morphologically differentiate between Plakobranchus species because of their highly variable colour patterns, since ethanolpreserved specimens tend to lose much of their original colouration (Figure 7). Museum collections as a source for taxonomic work, studies on historical ecology, or other kinds of biodiversity studies (Rainbow 2009, Hoeksema et al. 2011, Rocha et al. 2014), may not be sufficient without photographic documentation of the specimens in situ. It is suggested that illustrations be included in DNA research as well as included in GenBank data.

\section{Acknowledgements}

The expeditions were part of the research programme "Ekspedisi Widya Nusantara (E-Win)" of PPO-LIPI. The research permit application was sponsored by Prof. Dr. Suharsono of PPO-LIPI. LIPI granted research permit 6559/SU/KS/2007 for the fieldwork in the Raja Ampat Islands, West Papua. We want to thank Max Ammer and staff of Papua Diving at Kri Eco Resort and Raja Ampat Research and Conservation Center (RARCC) for logistic support at Kri Island, Raja Ampat. Dr. Mark Erdmann (Conservation International, Sorong, West Papua) provided useful advice and encouragement. Financial support was given by the van Tienhoven Stichting, the Schure-Beijerinck Popping Fund (KNAW), the Leiden University Fund, the Jan Joost ter Pelkwijk Fund (Naturalis), and the Alida M. Buitendijk Fund (Naturalis). We thank Erik-Jan Bosch (Naturalis) for making the maps. The authors thank three anonymous reviewers for critical remarks and the editor Nathalie Yonow for their help in improving the paper.

\section{References}

Adams MJ (2000) Blue-bellied plakobranchs. [Message in] Sea Slug Forum. Australian Museum, Sydney. Available from http://www.seaslugforum.net/find/2533

Apte D (2009) Opisthobranch fauna of Lakshadweep Islands, India, with 52 new records to Lakshadweep and 40 new records to India: part 1. Journal of the Bombay Natural History Society 106(2): 162-175.

Baba K (1936) Opisthobranchia of the Ryukyu (Okinawa) Islands. Journal Department Agriculture, Kyushu Imperial University 5: 1-50. [pls. 1-3] 
Barash A, Zeniper Z (1994) Notes on Opisthobranchia from the Red Sea - II. La Conchiglia 26: 7-9.

Bass AL, Karl SA (2006) Molecular phylogenetic analysis of genera in the family Plakobranchidae (Mollusca: Opisthobranchia: Sacoglossa). Records of the Western Australian Museum Supplement 69: 61-68.

Bergh R (1872) Malacologische Untersuchungen 2. In: Semper C (Ed.) Reisen in Archipel der Philippinen 2. CW Kreidel's Verlag, Wiesbaden, 376 pp. [42 pls]

Bergh R (1873) Neue Nacktschnecken der Südsee, malacologische Untersuchungen. Journal des Museum Godeffroy 1: 65-96. [pls. 9-12]

Bergh R (1887) Die van Hasselt'schen Nudibranchien. Notes from the Leyden Museum 9: 303-322. [pl. 6]

Bergh R (1905) Die Opisthobranchiata der Siboga-Expedition (1899-1900). Siboga-Expeditie Monographie 50: 1-248. [pls. 1-20]

Bertsch H, Johnson S (1981) Hawaiian Nudibranchs. Oriental Publishing, Honolulu, 112 pp. Burn R (1972) A guide to the Ascoglossa or sap-sucking sea-slugs of Australia. Australian Natural History 17: 174-178.

Christa G, Wescott L, Schaberle TF, Konig GM, Wägele H (2013) What remains after 2 months of starvation? Analysis of sequestered algae in a photosynthetic slug, Plakobranchus ocellatus (Sacoglossa, Opisthobranchia), by barcoding. Planta 237(2): 559-572. doi: 10.1007/s00425-012-1788-6

Clark KB, Jensen KR, Stirts HM (1990) Survey for functional kleptoplasty (Chloroplast symbiosis) among West Atlantic Ascoglossa (Sacoglossa) (Mollusca: Opisthobranchia). Veliger 33: 339-345.

Coleman N (2001) 1001 Nudibranchs - Catalogue of Indo-Pacific Sea Slugs. Neville Coleman's Underwater Geographic Springwood, 144 pp.

Coleman N (2008) Nudibranchs Encyclopedia: a Catalogue of Asia. Indo-Pacific Sea Slugs. Neville Coleman's Underwater Geographic, Springwood, 416 pp.

Colin P, Arneson C (1995) Tropical Pacific Invertebrates. Coral Reef Press, Beverly Hills, 296 pp.

Cuvier G (1830) La règne animal distingue d'àpres son organisation, pour servire de base à l'histoire naturelle des animaux et d'introduction à l'anatomie comparée. Déterville, Libraire, Paris Nouvelle Edition 2: [3] 1-504, [4] 1-584.

Debelius H (1996) Nudibranchs and Sea Snails. Indo-Pacific Field Guide. IKAN-Unterwasserarchiv. Frankfurt, 321 pp.

Deuss M (2009) Plakobranchus ocellatus from Mayotte Island - 1st variation. [Message in] Sea Slug Forum. Australian Museum, Sydney. Available from http://www.seaslugforum.net/ find/22643 http://www.seaslugforum.net/find/22643

Erhardt H, Baensch H (1998) Meerwasser Atlas 4. Wirbellose Tiere, Vol. 4. Mergus Verlag, Melle, 1214 pp.

Folmer O, Black M, Hoeh W, Lutz R, Vrijenhoek R (1994) DNA primers for amplification of mitochondrial cytochrome c oxidase subunit I from diverse metazoan invertebrates. Molecular Marine Biology and Biotechnology 3: 294-299. doi: 10.1186/1472-6785-13-34

Geiger D (2001) Plakobranchus from French Polynesia. [Message in] Sea Slug Forum. Australian Museum, Sydney. Available from http://www.seaslugforum.net/find/5436 
Gosliner TM, Behrens DW, Valdés Á (2008) Indo-Pacific nudibranchs and sea slugs. A field guide to the world's most diverse fauna. Sea Challengers Natural History Books, Gig Harbor, WA, 426 pp.

Gould AA (1852) United States Exploring Expedition....under the command of Charles Wilkes, Vol. 12, Mollusca and Shells.

Gouy M, Guindon S, Gascuel O (2010) Sea View version 4: a multiplatform graphical user interface for sequence alignment and phylogenetic tree building. Molecular Biology and Evolution 27: 221-224. doi: 10.1093/molbev/msp259

Gray JE (1840) Shells of molluscous animals. Synopsis of the British Museum 42: 105-152.

Groeneveld R (2006) Re: Plakobranchus ocellatus kind of mating. [Message in] Sea Slug Forum. Australian Museum, Sydney. Available from http://www.seaslugforum.net/find/15730

Guindon S, Dufayard J-F, Lefort V, Anisimova M, Hordijk W, Gascuel O (2010) New algorithms and methods to estimate maximum-likelihood phylogenies: assessing the performance of PhyML 3.0. Systematic Biology 59(3): 307-321. doi: 10.1093/sysbio/syq010

Händeler K, Grzymbowski YP, Krug PJ, Wägele H (2009) Functional chloroplasts in metazoan cells: a unique evolutionary strategy in animal life. Frontiers in Zoology 6: 28. doi: 10.1186/1742-9994-6-28

Heller J, Thompson TE (1983) Opisthobranch molluscs of the Sudanese Red Sea. Zoological Journal of the Linnean Society 78: 317-348. doi: 10.1111/j.1096-3642.1975.tb02263.x

Hervé JF (2010) Guide des nudibranches de Nouvelle-Calédonie et autres opisthobranches. Editions Catherine Ledru, Nouméa, 401 pp.

Hirose E (2005) Digestive system of the Sacoglossan Plakobranchus ocellatus (Gastropoda: Opisthobranchia): Light and electron microscopic observations with remarks on chloroplast retention. Zoological Science 22: 905-916. doi: 10.2108/zsj.22.905

Hoeksema BW, van der Meij SET (2008) Cryptic marine biota of the Raja Ampat island group: Preliminary results of the Raja Ampat Expedition (2007). National Museum of Natural History Naturalis, Leiden, 73 pp.

Hoeksema BW, van der Land J, van der Meij SET, van Ofwegen LP, Reijnen BT, van Soest RWM, de Voogd NJ (2011) Unforeseen importance of historical collections as baselines to determine biotic change of coral reefs: the Saba Bank case. Marine Ecology 32: 135-141. doi: 10.1111/j.1439-0485.2011.00434.x

Hughes RN (1977) The biota of reef-flats and limestone cliffs near Jeddah, Saudi Arabia. Journal of Natural History 11: 77-96. doi: 10.1080/00222937700770051

Imamoto J (2005) Plakobranchus ocellatus - variation F. [Message in] Sea Slug Forum. Australian Museum, Sydney. http://www.seaslugforum.net/find/13878

Jacobson P (2003) Nudibranch or Flatworm from Hawaii. [Message in] Sea Slug Forum. Australian Museum, Sydney. Available from http://www.seaslugforum.net/find/9295

Jensen K (1992) Anatomy of some Indo-Pacific Elysiidae (Opisthobranchia: Sacoglossa (= Ascoglossa)), with a discussion of the generic division and phylogeny. Journal of Molluscan Studies 58: 257-296. doi: 10.1093/mollus/58.3.257

Jensen K (1993) Morphological adaptations and plasticity of radular teeth of Sacoglossa (= Ascoglossa) (Mollusca: Opisthobranchia) in relation to their food plants. Biological Journal of the Linnean Society 48: 135-155. doi: 10.1111/j.1095-8312.1993.tb00883 
Jensen K (1996) Phylogenetic systematics and classification of the Sacoglossa (Mollusca, Gastropoda, Opisthobranchia). Philosophical Transactions of the Royal Society of London 351: 91-122. doi: 10.1098/rstb.1996.0006

Jensen K (1997a) Sacoglossernes systematik, fylogeni og evolution (Mollusca, Opisthobranchia). (Systematics, phylogeny and evolution of the Sacoglossa (Mollusca, Opisthobranchia). Vestjydsk Forlag, Copenhagen, 94 pp.

Jensen K (1997b) Evolution of the Sacoglossa (Mollusca, Opisthobranchia) and the ecological associations with their food plants. Evolutionary Ecology 11: 301-335. doi: 10.1023/A: 1018468420368

Jensen K (1997c) Sacoglossa (Mollusca, Opisthobranchia) from the Darwin Harbour area, Northern Territory, Australia. Proceedings of the Sixth International Marine Biological Workshop: The Marine Flora and Fauna of the Darwin Harbour area, Northern Territory, Australia, 163-186.

Jensen K (2007) Biogeography of the Sacoglossa (Mollusca, Opisthobranchia). Bonner Zoologische Beiträge 55: 255-281.

Kay EA (1979) Hawaiian marine shells. Reef and shore fauna of Hawaii. Mollusca. Bernice P. Bishop Museum Special Publication 4: 1-653.

Klussmann-Kolb A, Dinapoli A (2006) Systematic position of the pelagic Thecosomata and Gymnosomata within Opisthobranchia (Mollusca, Gastropoda) - revival of the Pteropoda. Journal of Zoological Systematics and Evolutionary Research 44: 118-129. doi: 10.1111/j.1439-0469.2006.00351.x

Koehler E (1998) Placobranchus mating behaviour. [Message in] Sea Slug Forum. Australian Museum, Sydney. Available from http://www.seaslugforum.net/find/427

Krampf M (2006) Plakobranchus ocellatus from Vietnam? [Message in] Sea Slug Forum. Australian Museum, Sydney. http://www.seaslugforum.net/find/17041

Krug P, Vendetti J, Rodriguez A, Retana J, Hirano Y, Trowbridge C (2013) Integrative species delimitation in photosynthetic sea slugs reveals twenty candidate species in three nominal taxa studied for drug discovery, plastid symbiosis or biological control. Molecular Phylogenetics and Evolution 69: 1101-1119. doi: 10.1016/j.ympev.2013.07.009

Maeda T, Kajita T, Maruyama T, Hirano Y (2010) Molecular phylogeny of the Sacoglossa, with a discussion of gain and loss of kleptoplasty in the evolution of the group. The Biological Bulletin 219: 17-26.

Marcus E (1982) Systematics of the genera of the order Ascoglossa (Gastropoda). The Journal of Molluscan Studies (Suppl.) 10: 1-31.

Marshall JG, Willan RC (1999) Nudibranchs of Heron Island, Great Barrier Reef - a survey of the Opisthobranchia (Sea Slugs) of Heron and Wistari Reefs. Backhuys Publishers Leiden, 269 pp.

Mehrotra R, Scott CM, Rohrer JM, Hoeksema BW (2015) Predation on a sacoglossan gastropod by a mushroom coral. Coral Reefs 34(2): 517. doi: 10.1007/s00338-015$1285-\mathrm{z}$

Montagu G (1804) VII. Description of several marine animals found on the South Coast of Devonshire. Transactions of the Linnean Society of London 7: 61-85. doi: 10.1111/ j.1096-3642.1804.tb00282.x 
O'Donaghue CH (1928) Report on the Opisthobranchiata with a comparison of the nudibranch fauna of the Red Sea and of the Mediterranean. (Cambridge Expedition to the Suez canal). Transactions of the Zoological Society of London 22: 713-841.

Ono A (2005) Plakobranchus variation - how many species? [Message in] Sea Slug Forum. Australian Museum, Sydney. http://www.seaslugforum.net/find/13970

Ostergaard JM (1955) Some Opisthobranchiate Mollusca from Hawaii. Pacific Science 9: $110-136$.

Pease WH (1860) Descriptions of new species of Mollusca from the Sandwich Islands. Proceedings Zoological Society, London 28: 18-37.

Pease WH (1871) Descriptions of nudibranchiate Mollusca inhabiting Polynesia. American Journal of Conchology 6: 299-305. [pls. 19-22]

Penn O, Privman E, Ashkenazy H, Landan G, Graur D, Pupko T (2010) GUIDANCE: a web server for assessing alignment confidence scores. Nucleic Acids Research 38: 23-28. doi: $10.1093 / \mathrm{nar} / \mathrm{gkq} 443$

Posada D (2008) jModelTest: Phylogenetic Model Averaging. Molecular Biology and Evolution 25: 1253-1256. doi: 10.1093/molbev/msn083

Puillandre N, Lambert A, Brouillet S, Achaz G (2012) ABGD, Automatic Barcode Gap Discovery for primary species delimitation. Molecular Ecology 21: 1864-1877. doi: 10.1111/j.1365-294X.2011.05239.x

Quoy JCR, Gaimard P (1833) Mollusques. In: Dumont d'Urville MJ (Ed.) Voyage de Découverts de l'Astrolabe, Éxécuté par Ordre du Roi Pendant les Années 1826-18271828-1829, sous le Commandement de M. J. Dumont d' Urville. Zoologie, Mollusques. Tome 2. Tastu, Paris, 686 pp.

Raabe C (2006) Plakobranchus ocellatus from the Philippines. [Message in] Sea Slug Forum. Australian Museum, Sydney. Available from http://www.seaslugforum.net/find/17395

Rainbow PS (2009) Marine biological collections in the 21st century. Zoologica Scripta 38 (Suppl. 1): 33-40. doi: 10.1111/j.1463-6409.2007.00313.x

Ramakrishna, Sreeraj CR, Raghunathan C, Sivaperuman C, Yogesh Kumar JS, Raghuraman R, Immanuel T, Rajan PT (2010) Guide to Opisthobranchs of Andaman and Nicobar Islands. Zoological Survey of India, Kolkata, 196 pp.

Rang PC (1829) Manuel de l'histoire naturelle des mollusques et de leurs coquilles: ayant pour base de classification celle de M. le baron Cuvier. Roret, Paris, 390 pp. [8 pls]

Rao KV (1962) On two opisthobranchiate molluscs, Placobranchus ocellatus Hasselt and Discodoris boholiensis Bergh, from Indian waters not hitherto been recorded. Journal of the Marine Biological Association of India 3(1-2): 253-256.

Richmond M (Ed.) (1997) A guide to the seashores of Eastern Africa and the Western Indian Ocean islands. Sida/Department for Research Cooperation, SAREC, Stockholm, Sweden, 448 pp.

Rocha LA, Aleixo A, Allen G, Almeda F, et al. (2014) Specimen collection: An essential tool. Science 344: 815-816. doi: 10.1126/science.344.6186.814

Ronquist F, Huelsenbeck JP (2003) MRBAYES 3: Bayesian phylogenetic inference under mixed models. Bioinformatics 19: 1572-1574. doi: 10.1093/bioinformatics/btg180

Rudman WB (1998) Plakobranchus ocellatus van Hasselt, 1824. [In] Sea Slug Forum. Australian Museum, Sydney. http://www.seaslugforum.net/find/placocel 
Rudman WB (2003) Comment on Tom Wyatt's Plakobranchus message by Mary Middlebrook. [Message in] Sea Slug Forum. Australian Museum, Sydney. Available from http:// www.seaslugforum.net/find/8958

Schmitt V, Anthes N, Michiels NK (2007) Mating behavior in the sea slug Elysia timida (Opisthobranchia, Sacoglossa): hypodermic injection, sperm transfer and balanced reciprocity. Frontiers in Zoology 4: 17. doi: 10.1186/1742-9994-4-17

Smolensky N, Romero M, Krug P (2009) Evidence for costs of mating and self-fertilization in a simultaneous hermaphrodite with hypodermic insemination, the opisthobranch Alderia willowi. The Biological Bulletin 216: 188-199.

Sreeraj CR, Sivaperuman C, Raghunathan C (2012) An annotated checklist of opisthobranch fauna (Gastropoda: Opisthobranchia) of the Nicobar Islands, India. Journal of Threatened Taxa 4: 2499-2509. doi: 10.11609/JoTT.o2783.2499-509

Stimpson W (1855) Descriptions of some of the new marine Invertebrata from the Chinese and Japanese Seas. Proceedings of the Academy of Natural Sciences of Philadelphia 7: 375-384.

Supapong A (2008) Plakobranchus ocellatus? from Bali. [Message in] Sea Slug Forum. Australian Museum, Sydney. Available from http://www.seaslugforum.net/find/20566

Swainson W (1840) A treatise on malacology; or the natural classification of shells and shellfish. Lardner's Cabinet Cyclopaedia. Natural History, Longman, London, 419 pp. doi: 10.5962/bhl.title.8027

Takano T, Hirano YM, Trowbridge C, Hirano YJ, Watano Y (2013) Taxonomic clarification in the genus Elysia (Gastropoda: Sacoglossa): E. atroviridis and E. setoensis. American Malacological Bulletin 31: 25-37. doi: 10.4003/006.031.0114

Trowbridge CD, Hirano YM, Hirano YJ (2011) Inventory of Japanese sacoglossan opisthobranchs: Historical review, current records, and unresolved issues. American Malacological Bulletin 29: 1-22. doi: 10.4003/006.029.0201

Trench RK (1969) Chloroplasts as functional endosymbionts in the mollusc Tradachia crispata (Bergh) (Opisthobrancha, Sacoglossa). Nature 222: 1071-1072. doi: 10.1038/2221071a0 Tuyen HT (2008) Re: Plakobranchus ocellatus from Vietnam? [Message in] Sea Slug Forum. Australian Museum, Sydney. http://www.seaslugforum.net/find/21422

van Hasselt JC (1824) Uittreksel uit eenen brief van Dr J.C. van Hasselt, aan Prof van Swinderen. Algemeene Konst- en Letter-bode voor het jaar 1824: [2] 20-24, [3] 34-39, [4] 54-55.

Vayssière A (1912) Recherches zoologiques et anatomiques sur les Opisthobranches de la Mer Rouge et du Golfe d'Aden, partie 2. Annales du Faculté des Sciences de l'Université de Marseille 20: 5-157.

Wägele H, Stemmer K, Burghardt I, Händeler K (2010) Two new sacoglossan sea slug species (Opisthobranchia, Gastropoda): Ercolania annelyleorum sp. nov. (Limapontioidea) and Elysia asbecki sp. nov. (Plakobranchoidea), with notes on anatomy, histology and biology. Zootaxa 2676: 1-28.

Wägele H, Deusch O, Händeler K, Martin R, Schmidt V, Christa G, Pinzer B, Gould SB, Dagan T, Klussmann-Kolb A, Martin W (2011) Transcriptomic evidence that longevity of acquired plastids in the photosynthetic slugs Elysia timida and Plakobranchus ocellatus does not entail lateral transfer of algal nuclear genes. Molecular Biology and Evolution 28: 699-706. doi: 10.1093/molbev/msq239 
Warren L (2000) Another species? of Plakobranchus. [Message in] Sea Slug Forum. Australian Museum, Sydney. Available from http://www.seaslugforum.net/find/2135

Wyatt T (2003) Plakobranchus ocellatus in aquaria. [Message in] Sea Slug Forum. Australian Museum, Sydney. Available from http://www.seaslugforum.net/find/8912

Yamamoto S, Hirano YM, Hirano YJ, Trowbridge CD, Akimoto A, Sakai A, Yusa Y (2013) Effects of photosynthesis on the survival and weight retention of two kleptoplastic sacoglossan opisthobranchs. Journal of the Marine Biological Association of the UK 93: 209-215. doi: $10.1017 /$ S0025315412000628

Yonow N (1990) Red Sea Opisthobranchia. 3.The orders Sacoglossa, Cephalaspidea, and Nudibranchia: Doridacea (Mollusca, Opisthobranchia). Fauna of Saudi Arabia 11: 286-299.

Yonow N (2008) Sea slugs of the Red Sea. Pensoft Publishers, Sofia-Moscow, 304 pp.

Yonow N (2012) Opisthobranchs from the western Indian Ocean, with descriptions of two new species and ten new records (Mollusca, Gastropoda). ZooKeys 197: 1-129. doi: 10.3897/zookeys.197.1728 